\title{
Reconstruction of pastoral and theological education in tropical Africa: A review of the case of St. Andrew's College, Kabare
}

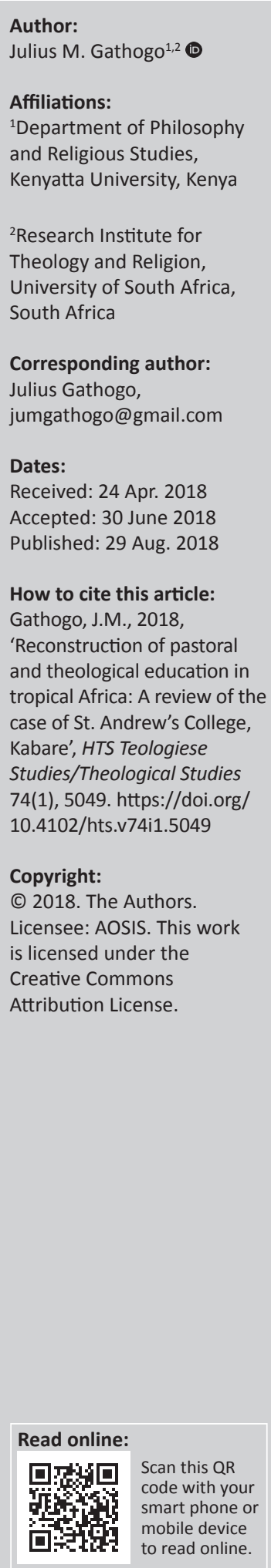

The article sets out to demonstrate the need for theopastoral education in tropical Africa, by showcasing St. Andrew's College, Kabare, in Central Kenya. The statement of the problem therefore is: How has St. Andrew's College, Kabare, journeyed with its establishment as a centre of theopractical education? This will drive us to methodologically employ historicalanalytical design in our bid to understand the intrigues behind the formation and growth of the institution. As it prepares to graduate from a diploma college to a university, how has it wrestled with the challenges in its endeavour to reconstruct theological and pastoral education? The article sets on the premise that the nature of theological articulation in the East African region, as propounded by the then-all powerful East African Revival Movement, needed theopastoral reconstruction via establishment of an institution that would thoroughly address relevant concerns. To this end, the first synod of the diocese of Mt Kenya East, held at St. Andrew's Church, Kabare, on 26 August 1975, requested the standing committee of the synod to appoint a commission to investigate the future plans of lay and clergy training and report this matter to the next synod. In other words, the first synod of the new diocese foresaw the birth of St Andrew's as a centre of theological education and holistic training. In view of this, the article will explore the intrigues behind this process in a bid to show its relevance for the rest of the tropical Africa.

\section{Introduction}

In addressing theopractical education in tropical Africa, it is important to appreciate that the term 'education' is etymologically derived from the Latin words educatum and educare (educere). Educere means 'train', 'mould, 'lead out', 'bring up', 'provide schooling' and so on. The Latin educatus, as educere, means 'bring up (children)', 'to train', and 'lead forth', just as in the Italian educare, Spanish educar and French éduquer (Gathogo 2013). In my view, 'education', as a term, is largely used in my Kenyan context to mean 'schooling', but as Jesse Mugambi says, 'education is the preparation of a person for responsible and mature participation in the life of his or her community' (Mugambi 1995:136). Indeed, schooling is one of the methods of achieving this goal.

This all-embracing perspective in education led the great Indian nationalist Mahatma Gandhi to say, 'By education, I mean an all-round drawing out of the best in child and man's body, mind, and spirit' (Nieto 2003:17). In the foregoing, education is both unilateral and bipolar, a process of continuous knowledge seeking and the development of various aspects of human personality. It stabilises social order through professionalism, conservation of culture, and eventually acts as the catalyst of positive social transformation and social reconstruction. And despite the dynamism of life, its noble aim is to bring desirable changes in the universe.

In learning from the ancient Greeks, '[e]ducation is a second sun to its possessors', as philosopher Heraclitus noted. Further, Antiphon wrote thus:

The first thing, I believe, for [humanity] is education. Whenever anyone does the beginning of anything correctly, it is likely also that the end will be right. As one sows, so can one expect to reap. If in a young body one sows a noble education, this lives and flourishes through the whole of his [sic] life, and neither rain nor drought destroy it. (Freeman 1952:21)

\section{According to Philosimply:}

Antiphon was an ancient Greek philosopher born in the Athenian village Rhamnous in 480 BC. He was a sophist, one who taught rhetoric (public speaking), as well as a public speaker (orator), and a politician. 
Like other sophists, he believed that he could make a weaker argument appear to be the stronger, which he displayed in his work the Tetralogies, where he argues for both sides of fictitious murder cases. As a politician, he supported oligarchy (rule by few) and the rise of the oligarchic regime the Four Hundred. Ultimately, he would have to defend his own life using his public speaking skills when the Four Hundred were removed and replaced by a democracy and as a supporter he was brought to trial (http://www.philosimply.com/philosopher/antiphon, accessed 15 April 2018).

In understanding the contextual nature of education, it is critically important to recall the Athenian education, which was basically for culture. Kenneth J. Freeman has noted thus: 'To a Hellene, education meant the training of character and taste, and the symmetrical development of body, mind and imagination' (Freeman 1907:43). Indeed, in Athens (ancient Greece) education was designed to produce an Athenian. It was designed to produce an Athenian citizen. As T. R. Glover (1931:18) wrote, 'The work of the Greeks is, above all things, the discovery of the individual'. As William Barclay has noted, 'The aim of Athenian education was to produce Athenians, who loved beauty and who loved Athens, and who were prepared to serve Athens in peace and in war'. Similarly, in the Kenyan context, the goals of education include fostering patriotism and national pride and promoting individual development, self-fulfilment, moral values and social responsibility, among others. In view of this, prudent education management of our resources and effective teacher leadership falls within the noble goals of education.

Further, in exploring theopractical education in tropical Africa, and in reference to St. Andrew's, Kabare, it is critical to appreciate the Greek heritage as of immense value to Christian theological education. As church historian Freeman Butts (1947) observes:

We think the way we do in large part because the Greeks thought the way they did. Thus, to understand our own ways of thinking we need to know how the Greeks thought. (p. 45)

Given this dependence upon Greek thought in so-called modern education, educational thought and practice reflect the distinctiveness of the Greek intellectual heritage. In particular, Socrates maintained that knowledge itself was a virtue. For him, to really know what is good is to prohibit one from doing evil. He stressed the place of reason and logic, with thinking itself viewed as objective reasoning. To Socrates, human reason was the means by which to discern divine revelation and its implications for all of life. Interestingly, even though Socrates (and other Greek philosophers) stressed the importance of moral life, he did not do so in terms of the God of Christendom. Similarly, Plato, who defined education as the training in excellence from youth upwards and what makes a person passionately desire to be a perfect citizen, as it teaches him or her to rule with justice, viewed the ideal as real, with actualities as mere copies of the transcendent and perfect ideal. This aspect of Plato's thought was particularly attractive to Christian thinkers like Augustine, who later synthesised these insights with the Christian faith. Further, Plato's view of an ideal world, which exists in the theory of forms, fostered a concern for social and political reforms as a fruit of education in the lives of those persons who grasped the ideals. Education in tropical Africa, and in particular at St. Andrew's College, Kabare, draws its inspiration from these trajectories.

\section{Background of St. Andrew's, Kabare}

Theological education in Central Kenya, prior to the establishment of St. Andrew's College of Theology and Development, Kabare, in 1977, was heavily influenced by untrained lay theologians, the leaders of the East African Revival Movement (EARM). In turn, the revival, whose presence cut across all of East Africa (Kenya, Rwanda, Burundi, Tanzania and Uganda), was downright heretical and legalistic. After its birth in Rwanda in 1927, it spread quickly within the rest of East Africa, imparting new Bible study trajectories, new ways of confessing Christ and 'new' ways of leading Christian lives. It also operated as a church within a church - a church that went beyond denominational confines; hence it was seen among Presbyterian churches, the Anglicans, Methodists and other mainline churches. Theologically, it insisted on unrealised eschatology (future heavenly concerns as opposed to earthly concerns). Those who subscribed to its teachings were encouraged to uphold a variety of dos and don'ts. That is, don't keep dogs or watchmen for security reasons in your compound as God protects Christian believers; don't subscribe to the so-called modern forms of marriage ceremonies, as the 'brethren' would pray, find one's suitor and assist the new bride and bridegroom to conduct the 'holy' ceremony, among others. They would also encourage believer-subscribers to avoid bank loans, as Parousia (the second coming of Christ) may find an indebted believer who would then be condemned to eternal punishment, among others. They also encouraged men to shave their beards and remain 'clean' as they also encouraged young women to wear long dresses that would discourage men's 'evil' and pervasive thoughts.

With the EARM and its untrained theology dictating the theological trajectories of the day and with a shortage of 'trained' clergy in the Mount Kenya region of the Anglican Diocese, the need for a vibrant centre for theological education was necessary. With David Gitari (1937-2013) taking over as the Bishop of Mount Kenya East in 1975, after the subdivision of the larger Mount Kenya Diocese, which was all headed by Bishop Obadiah Kariuki (1902-1978), the establishment of a centre for 'thorough' theological education was no longer a pipe dream; hence the reconstruction of theological discourses across the region was desperately needed. In the new dispensation, Gitari took over the newly hived of Anglican Diocese of Mt Kenya East while Kariuki now became the Bishop of Mount Kenya South. Shortly after, Kariuki's health started deteriorating, from bad to worse, thereby forcing the diocese of Mt Kenya South to recall the then-provincial secretary (Sospter Magua) to return from church headquarters 
and take over from Bishop Kariuki in 1976 (Cole 1970). Being among the only two Kenyan Anglican Bishops with a theological degree, Gitari insisted on sound theological knowledge for both the laity and clergy. His sermons, as a bishop and later Archbishop of Kenya from 1975 to 2002, were more like mass Bible study sessions where he taught on key theological themes. Such themes included God and ecology, salvation in the African context, salvation and liberation, church and politics, God and women, land rights and the Bible, God and theodicy, death and resurrection, situational ethics and the making of a Christian, thanatology and Christian faith, salvation and mature Christianity, and so on.

Of interest to note is that the effect of EARM was clearly felt among clergy whose church elders were adherents of the movement. Positively, the revival movement also emphasised the virtues of forgiveness, forging ahead even when matters are hard to bear, apologising when one is in the wrong and general acts of hospitality. As a participant observer, I always encountered the victims of Kenya's war of independence (the Mau Mau Rebellion of 1952-1960) openly expressing words of forgiveness, even though some of their relatives had been killed by known killers 25 years earlier. With such a strong force in the ecclesiastical scene and with theological divergences evident even among the clergy, a centre for theological education, St. Andrew's, was mooted in 1975-1976 but actualised in 1977. Further, the fact that the other centre for pastoral training, McGregor Bible School, Weithaga, was not adequate for 'thorough' theological education, in my view, is clear when we mull over the fact that the tutors were not adequately educated to handle the challenge. Again, the vast area of the Mount Kenya region could not be served by one institution, McGregor. Another centre was needed, and as time wore on, it overshadowed the latter to the extent that by the turn of the 21st century McGregor was forced to become a centre of refresher courses for Anglican lay readers in order to keep from closing its doors.

With time, Gitari's Mount Kenya East Diocese was subdivided into Kirinyaga, Embu, Mbeere, Meru and Marsabit Anglican Dioceses. In turn, each of these five dioceses were by 2017 headed by five bishops, all of whom had studied at St. Andrew's College, Kabare, at different times. Equally, Bishop Kariuki's or Bishop Magua's diocese of Mt Kenya South had by 2017 been subdivided into five dioceses, namely: Mt Kenya West, Mt Kenya Central, Mt Kenya South, Murang'a, and Thika. By 2017, both the former dioceses of Mount Kenya East and Mount Kenya South relied on St. Andrew's College, Kabare, for the training of their respective clergy. Similarly, other Anglicans and non-Anglican churches within, and outside, East Africa have undertaken theological training at St Andrew's College, Kabare, since 1977.

\section{The goal of founding St. Andrew's College, Kabare}

Various schools of thought have been explored to ascertain the key reason behind the establishment of St. Andrew's College, Kabare, despite the former Mount Kenya Diocese having McGregor Bible School, Weithaga, in the present day Murang'a County, which was training clergy from the Mount Kenya region. Firstly, after the diocese of Mount Kenya under Bishop Obadiah Kariuki was subdivided into two, Bishop Kariuki was assigned the task of stewarding one side (Mt Kenya South), while the newly consecrated Bishop David Mukuba Gitari took over Mount Kenya East, which covered nearly half of Kenya. It covered the present-day Kirinyaga, Meru, Embu, Tharaka-Nithi, Isiolo, Marsabit and Garissa Counties and parts of Samburu and Wajir Counties. Its vastness can be explained in considering that Meru and Marsabit are geographically large, indeed among the largest counties in Kenya, while Embu, Kirinyaga, Meru and Tharaka-Nithi are some of the most densely populated counties in Kenya. This partly informed the need for a theological school for the region, among other factors that are considered in this book.

Secondly, after David Gitari was consecrated at Emmanuel Church, Kigari, Embu, in 1975, he found there was a shortage of clergy in the new Mt Kenya East Diocese. According to an eye witness (Joseph Karuri), Gitari told the serving clergy to recommend some 'capable' Evangelists for a crash programme that would ultimately lead to ordination as priests (J.T. Karuri [St. Andrew's Kabare] interview, 10 April 2017). Certainly, desperate times call for desperate measures. Gitari, who did not believe in crash programmes for clergy, was forced to take that route in order to mitigate the problem he faced in the vast diocese as he worked toward a comprehensive way forward. Subsequently, he started the theological training class at the Embu diocesan headquarters. This training took 9 months, after which clergy were ordained and posted in various parishes and subparishes. For fear that they would perform dismally, Gitari gave the newly ordained priests a 10-year contract, after which he hoped to retire them. In planning to retire the 'crash-programme clergy', he hoped that a more theologically 'qualified' team would have been created. To his surprise, the crash-programme clergy did an exemplary job in the parishes, such that he did not retire any of them. He even promoted some to become rural deans, archdeacons and so on.

Thirdly, although the last Synod of Mt Kenya Diocese under Bishop Kariuki, in 1975, recommended that the new dioceses of Mt Kenya South and Mt Kenya East should continue to train their clergy at McGregor Bible School, Weithaga, Murang'a County, Gitari found issues that overruled those recommendations. The fear then was that starting another theological training institution would be too costly for the new diocese of Mt Kenya East. Gitari could not understand the cause of fear amidst faith in the God of Christendom. As he used to say, 'God has not given us the spirit of timidity, but of power, love, and discipline' (2 Tm 1:7) (Gitari 2014).

Fourthly, Gitari's meeting with Bishop Kariuki's immediate successor, Sospeter Magua, to discuss how the resolutions of the 1975 synod would be implemented left him flabbergasted, as their theological positions differed sharply. In particular, 
they discussed how the two dioceses (Mt Kenya East and Mt Kenya South) were going to jointly make use of McGregor Bible School. Having graduated with a Bachelor of Arts, Bachelor of Divinity and a Diploma in Theology, in those early days (1960s) in our Kenyan history, Gitari was, in a sense, in a world of his own. He was not just a believer but also a well-trained scholar who critically weighed matters deeply. As a result, he differed with Bishop Magua on the philosophies behind the recruitment of trainees, the mode of training, the curriculum, the contents of the training, the language and mode of instructions, and the general approaches to theological training. While instruction, for instance, could be offered in the vernacular (Kikuyu) at McGregor Bible School, owing to the low recruitment grades of the trainees, Gitari would hear none of this. Having inherited the part of the diocese that had various ethnic nationalities such as Kikuyu, Gabra, Bulji, Borana, Samburu, Somali, Embu, Meru and Kamba, he thought it is critically important to recruit only trainees who had acquired a form four Division 3 (current Grade C) and above. To put it differently, Gitari, like Plato in his 'ideal state', wanted ecclesiastical leaders, or other leaders for that matter, to be men and women who must be the top cream of society, in terms of educational background. In one of his principles for an ideal state, the Greek philosopher Plato held that rulers must govern in virtue of knowledge of the truth. They must be the top cream (finest fruits) of education provided by the state. Rulers should be educated in all fields, that is, in the social and physical sciences. They must also master the temptations of the flesh. They must have passed military training and held position of administration (Brown 1968). Without going to the Platonic extreme, Gitari rightly saw the danger of hiding behind the 'call to the ministry' in recruiting candidates who would not comprehend deep theological and contemporary concerns.

Nevertheless, Gitari's fear of recruiting low-grades candidates for theological training is also captured by Jesse Mugambi in his book, From Liberation to Reconstruction (1995). In view of this, Mugambi expresses his neo-Platonist view that genuine positive social transformation is best done when an organisation has a well-qualified labour force, and trainees for that matter. In regard to the church, he says that serving church personnel need to be retrained, and the training of new Personnel will need review' (Mugambi 1995:179). In particular, he contends that African churches ought to ensure that their lay and ordained workers are at least as well trained as their counterparts in the public and private sectors. To ensure this, minimum recruitment standards 'and training requirements will need to be brought to parity with those of the public and private sectors' in each country. Mugambi further contends that this will be 'an important step towards the restoration of declining confidence in Church leadership' (Mugambi 1995:179). Did Gitari fear that the church would lose credibility if it recruited low-grade candidates in future?

While propounding the view that ecclesial reconstruction would require the church to raise the skills level of its workers and especially the clergy, Mugambi cautions about the danger of acquiring an education abroad, which is not relevant to the needs at home. He does not rule out, however, the thought of giving opportunities to those who are already trained in Africa to travel abroad for the purpose of international exposure. In seemingly appearing to build on Gitari's quest for highly academic recruits for theological training, Mugambi introduces the idea of an 'electric Church'. Hence, in modern technology, Mugambi sees the priority of the African churches as to establish 'the electronic Church' (Mugambi 1995:154). In other words, he sees the modern church as the best placed to use electronic technology for its edification, without insulting the intelligence of Africans. Electronic media, through the radio and television, Mugambi argues, should be used not to amuse, as it has been used in the past, but to educate without losing its ecumenical edge (Mugambi 1995).

Like Mugambi, who bases his proposal on the historical evidence of North African theologians such as Tertullian, Cyprian and Augustine, who 'were intellectually and culturally close to the Hellenistic tradition, North Africa had its own significance in the shaping of basic Christian doctrines' (Mugambi 1995:63). Gitari could only see an intellectually vibrant church when theology was done by the top cream of the society. Was he mistaken? Did he fail to contextualise the matter? Did he fail to understand the African contexts of poverty, semi-illiteracy and imprints of colonial injustices, among other concerns, in raising the bar for theological training? By no means, no. Considering that the alumni of St Andrew's College, Kabare, are playing critical theosocial roles locally and abroad 40 years later (1977-2017), Gitari's fear of recruiting low-grade recruits for theological training was certainly correct. It demonstrated his great vision for theological training within and beyond the Mt Kenya region.

Fifthly, Gitari could not understand how theological training was to be defined and dictated by untrained, lay church leaders in the so-called EARM. In turn, the EARM had its roots in Rwanda. The seed was sown in the 1920s and 1930s when in September 1929 two persons, Dr Joe Church and Simeoni Nsibambi, undertook serious Bible study on the Holy Spirit. Dr Church was a medical European missionary doctor who had gone to Gahini in Rwanda to help during a period of drought and famine. Simeoni was from Uganda. As a result of the study, the two sank into deep spiritual experience. The experience became the driving force that led to a series of conventions. These conventions include the Gahini Convention of 1933, the Kabale Convention of 1935 and the Mbarara Convention of 1936, among others. While the three noted conventions took place in Rwanda (Gahini) and Uganda (Kabale and Mbarara), the revival had reached Maseno of Western Kenya as early as 1937.

After the Arahuka [Arise] revival in Central Kenya in 1967, the pietistic movement, despite its heresies, became the be-all and end-all of all ethical issues facing Christians in the Protestant strand of mainline churches (Presbyterians, Methodists and, more importantly, the Anglican Church). It was they who 
advised on who should preach, pastor, lead and so on. As the name suggests, the EARM was initially meant to revive spirituality in the church in general. Since 1927 when it was born in Rwanda, spread to Uganda and Kenya and in the rest of Eastern Africa, the membership of the movement has been non-denominational, non-sexist, non-racial, and non-ethnic, among other polarising dimensions. From its Rwandan origin, it thus spread its wings to the rest of the East African countries quickly, even though it was too legalistic. It forbade beer drinking, smoking, taking snuff, clitoridectomy (female genital mutilation) or 'circumcision' of girls and social relationships between girls and boys; indeed all unmarried persons must constantly confess not only their personal encounters with Christ on as many occasions as possible but more importantly their marital faithfulness. It was the responsibility of elders in the movement to arrange the marriages of its young members, which meant that courtship was not necessary. Any member who went against this code was excommunicated. Despite having a very legalistic stance, and even though they remained a church within a church, they turned out to be very influential, especially in the 1970s and 1980s.

In an interview, Pam Wilding, a church missionary society (CMS) missionary from the UK, confessed to me that she had to remove her earrings when she came to St Andrew's College in 1988 to pioneer the business school in order not to offend the brethren. She also had to plead for the secretarial students to be able to avoid plaiting their hair and not to wear jewellery because they would have to look smart to work in Kenya's offices. Certainly, the revivalists emphasised strictness in all spheres of life to the extent that it was difficult to cope with some of their legalistic tendencies. Nevertheless, their emphasis on modest clothing, especially for women, was not totally bad save for the fact that it was not theologically justifiable.

\section{Theological divergences}

In his book, Troubled But Not Destroyed (2014), Gitari confesses that they could not agree with Bishop Magua because he wanted to see trainees at McGregor Bible School, Weithaga, who were 'mature' and who had been selected from the EARM (also called Balokole, the 'saved ones') (Gitari 2014). Certainly, the Balokole were equally troubling to the clergy, who were necessarily made to constantly seek their approval in order to appear 'called' and/or committed to the spread of the Gospel. Any clergy who failed to seek their approval were easily dismissed by the EARM as Muriithi-wa-Mucara [a shepherd whose focus was salary and not heavenly pursuits]. It was commonplace to hear members of the EARM discussing and 'complaining' about clergy who were not 'genuinely called' to serve God, especially if a clergyman disagreed with their parallel church leadership within the church. Hence, the revivalists ensured that there was a dualistic church leadership of laypeople with no theological training, while the trained clergy led the other team, the conventional church. To avoid unnecessary tensions and disagreements with them, most clergy chose to 'agree' with their theological standpoints despite their legalistic positions that were downright heretical and utopian. As a matter of fact, it was no surprise to see highly theologically trained clergy 'agreeing' with the revivalists (in their parishes) that 'it was ungodly to keep dogs' or watchmen for security reasons, as God is the ultimate giver of security. Others would insist that the Brethren (Balokole) must not take bank loans because that amounted to spiritual unpreparedness in case 'God came like a thief' and took them when they were indebted, as they would miss heaven (refer to $1 \mathrm{Th}$ 5:2). Other revivalists within the EARM discouraged the clapping of hands or laughter in the church as it amounted to 'being carnal' or ungodly for that matter. As Gitari was consecrated as the local bishop in 1975, he had a well-curved job: that is, to heal the society pastorally through establishing a theological college that would counter heretical teachings and offer sound scriptural teachings and apt theological education that would stand the test of time.

Thus, while Gitari wanted a full 3-year theological training for clergy, Magua was vouching for retiring primary school teachers, revivalist lay readers, evangelists and the like, who would be 'trained' for only 6 months. These would then be ordained and posted as priests of the Anglican Church. Having been 'trained' in the revivalist school of thought for a long period, it was hoped that the crash-programme clergy would get fully prepared within 6 months for pastoral ministry. Of importance to note is that Bishop Magua wanted McGregor Bible School to remain an Anglican theological setup but Gitari was looking forward to an establishment of a theological university that would go beyond denominational cocoons. Gitari (2014) confesses thus:

I wanted well-qualified young people who were committed Christians and who had scored at least a 3rd division [Grade $\mathrm{C}$ ] in their form four examinations. They would then undergo a three-year theological education before ordination. (p. 44)

Theologically, God works in mysterious ways. Some of the above contestations were theologically relevant in that they catalysed the establishment of St Andrew's College, Kabare, which had humble beginnings. Indeed, it started in May 1977 in the Diocesan Office, Embu, but later moved to the present site, St Andrew's Kabare, in 1978. To this end, Gitari concedes that when the diocese of Mt Kenya East was getting subdivided in 1990, the college had already trained 125 men and 8 women. Out of the 133 trained alumni of Kabare then, 20 of them were Kenyan Anglicans, while others were from the neighbouring countries: Ethiopia, South Sudan and Tanzania (Gitari 2014). In view of this, St Andrew's had managed to go beyond denominational dictatorships, had embraced an ecumenical spirit in theological education and had enriched itself in cultural diversity through its international admissions of trainees and through the international members of its teaching staff.

\section{Synod recommendation to start St. Andrew's}

During the last synod of the diocese of Mt Kenya, at Kahuhia, under Bishop Obadiah Kariuki, from 15 to 16 April 1975, 
a resolution regarding the status of McGregor Bible School, Weithaga, was made as follows:

As capital expenditure to start a second such establishment would be prohibitive, it is recommended that McGregor Bible School should serve both Dioceses for the foreseeable future, all assets and liabilities be owned jointly by the two Dioceses and [shall] operate within an inter-Diocesan management committee. (Synod 1990:174)

In turn, the first synod of Mt Kenya East was held at St. Andrew's Church, Kabare, on 26 August 1975. In this synod meeting of August 1975 (for Mt Kenya East), the April 1975 Synod recommendation (of the larger Mt Kenya Diocese) on McGregor was deliberated upon. Subsequently, the August 1975 Synod passed a cautious resolution as follows:

This Synod approves and endorses the work of McGregor School and wishes to continue sending students there from this Diocese [of Mt Kenya East] but requests the Standing Committee of the Synod to appoint a Commission to investigate the future plans of lay and clergy training and report this matter to the next Synod. (Synod 1990:174)

In their deliberations of 13 March 1976, the Theological and Liturgical Committee expressed their opinion that the diocese of Mt Kenya East should start its own theological training centre. This proposal was reported to the Standing Committee on 27 March 1976. The need for another Bible school was further energised because McGregor Bible School, Weithaga, had by then suspended further training in the whole of 1976 and the first half of 1977. This means that the Joint Management Committee that was appointed on 15 April 1975, which should have comprised people from the two dioceses, did not take place. Hence, the committee remained a mere proposal. By then, the Bishop (Obadiah Kariuki) had missed out on several occasions as he was reportedly ailing. The Joint Management Committee meeting was finally called at Weithaga in early 1977. This meeting came after the consecration of the second bishop (Sospeter Magua) of Mt Kenya South on 30 October 1976 (Synod 1990).

During the early 1977 meeting under Bishop Magua, the convener, there was no clear agreement on how to manage McGregor Bible School. In other words, the two bishops in attendance differed on virtually everything. That is, their divergent theophilosophical approaches pointed to the fact that the birth of a second college of theology, within the larger Mount Kenya region, was a matter of urgent concern, especially on the Mt Kenya East side of the former Mt Kenya Anglican Diocese. As a result, the representatives from Mt Kenya East returned to the Embu diocesan headquarters determined to recommend the starting of a diocesan Bible school and/or centre for theological education. Interestingly, St Andrew's Bible College opened its doors to its first eight students on 01 July 1977, two months before McGregor Bible School, Weithaga, re-opened for its Mt Kenya South students. After the Mt Kenya East Synod passed a resolution in 1977 to start St. Andrew's Bible School, the new diocese found itself in dilemma - that is, between St Andrew's Bible School and
St Paul's Cathedral, Embu, which one should be built first, owing to the fact that its resources were limited?

\section{St. Paul's Cathedral or St. Andrew's College?}

Having sold the idea of building a college for theological education to the diocesan synod, and upon its subsequent approval, Bishop David Gitari and his team found themselves in a dilemma. Considering that the new diocese of Mt Kenya East had a hotchpotch of unresolved issues and/or a variety of needs, the diocesan synod had to decide on whether to first build a diocesan cathedral (central church under a provost) or put up a theological college (St Andrew's Kabare). Whatever decision was made, the limited resources remained an impediment to the progress in whatever direction that they were to undertake.

In his eighth and last bishopric charge, as the bishop of the diocese of Mt Kenya East, at the St. Andrew's Church, Kabare, Synod of 02-04 May 1990, David Gitari highlighted his 15 years of theological education. He says:

In early 1977, we had an interesting discussion on what should be built first: A Cathedral or a Bible School. We gave the Bible School a higher priority in view of the fact that there was greater urgency for training people for the Ministry to meet the needs of our Parishes, including the Cathedral. In July 1977, we started our Bible School in the Diocesan Office, Embu, and later moved it to [St. Andrew's] Kabare with full approval of the Third Synod. (Gitari 1990:1-2)

\section{Gitari (1990) went on to say:}

St. Andrew's Institute has now become the leading Bible College in the whole [Anglican] Province. We are grateful to EZE, World Vision, United Thanks Offering of ECUSA, CMS, and Bread for the World who contributed towards the capital development of St. Andrew's [College, Kabare]. (pp. 1-2)

The synod resolution to give priority to the building of St Andrew's College, Kabare, rather than first building St Paul's Embu Diocesan Cathedral turned out to be a great milestone indeed. Undoubtedly, the college created jobs for some locals, some as suppliers, workers, cow attendants, watchmen, cooks, caretakers, cleaners, and so on. Tutors were hired from various parts of the world: Britain, Australia, Rwanda, Kenya and from various corners of the country. As one of the well-staffed theological colleges in Kenya and the East African region, St. Andrew's College, Kabare, turned out to be a pan-African institution that attracted students from the Democratic Republic of Congo (then Zaire), Tanzania, Uganda and Sudan, among other places. Apart from the diocese of Mt Kenya East, other Anglican dioceses begun to send their trainees for theological education at St Andrew's College. Similarly, other ecclesiastical denominations, including the African Instituted Churches, also began to send students for theological training. Like the mustard seed (Mt 17:20) that grew by faith, from a mere seed to a huge tree that bore fruit for all to consume, St Andrew's had gone beyond all expectations within a mere 10 years (1977-1987). 
By May 1990 when the diocese of Mt Kenya East was getting subdivided into Kirinyaga and Embu Dioceses, St. Andrew's College, Kabare, had trained people from various counties, dioceses, and countries (Table 1).

In other words, Table 1 shows that the theopastoral reconstruction project (St Andrew's College, Kabare) finally succeeded despite the noted challenges. And as the influence of the EARM decreased from the mid-1990s to date, the Kabare project remains a key factor in dismantling the huge 'empire' that was a 'church within a church'. Was St. Andrew's College, Kabare, the only factor that weakened its hold on society? By no means, no. There vibrant ministry of Afro-Pentecostalism has also helped in weakening the revival movement, especially its ability to attract young urbanised and educated people. Nevertheless, St. Andrew's College, Kabare, remains a critical institute for theopastoral reconstruction of traditional theologies, which were untrained and largely laity-led. It has lessons for the rest of tropical Africa, as the challenges are interrelated.

\section{Practical education and training}

From its humble beginning at Embu Diocesan Office in 1977, the mode of instruction and training at St. Andrew's Kabare has always been praxiological, a phenomenon where theory and practice are always combined. To bring in the practical aspect, St Andrew's has always exposed students to practical education through block placements, Sunday placements, weekly sermon evaluations, sharing parish experiences and a mentorship programme.

By block placements, individual students were sent to particular parishes after the college consulted specific priestsin-charge (L. Mwaniki, interview, 08 June 2017). The purpose of consulting the parish priest is to seek confirmation that the parish was ready to accommodate a particular student and provide all the necessary requirements such as food, accommodation and general upkeep for 4-5 months. In practice, students were normally sent for block placements during the holidays. In the assigned parishes, they were expected to be coached by the serving clergy on matters to do with office management, keeping files, categorising information, dealing with fellow church workers and especially the juniors, administering Holy Communion, chairing church or parish committees, attending to disciplinary matters and so on. Although most of these issues were taught at the college, practical encounters were now given attention during the block placements. During that time, each lecturer and tutor was assigned a manageable number of students whom he or she had to monitor till the block placement was over. At the end of the block placement, the priest-in-charge was supposed to write a comprehensive report about the student who was serving in his or her parish. In such reports, the priest would report on areas that the student needed to improve upon. In such situations, tutors would swim into action and address the weaknesses noted by the parish priest. In some isolated cases, especially where a student misbehaved or committed a serious misdemeanour, the parish priest could provide evidence that would eventually lead the college to write a letter to the Bishop's Examining Committee that would recommend that the said person be denied ordination.

In regard to Sunday placement, students were allocated to the various parishes cutting across the former Mt Kenya East (L. Mwaniki, interview, 08 June 2017). In some cases, they were given transport by the college for such movements. In other cases, the college driver would take them to the scattered parishes, especially in the interior parishes where normal public transport system was a challenge. While the block placement was on a monthly basis, the Sunday placement was on term or semester basis. As in the former, students sent to the various parishes were assigned pastoral roles such as preaching, teaching catechism classes and leading the Sunday worship, and in some cases they could be requested to come on a Saturday. In such scenarios, the particular parish would meet their transport costs and other needs. The aim of these developments was to shape their ministerial formation. Of importance to note is that while block placement was purely for theological students only, Sunday placements were for all students. This included the ones from the business and secretarial class. The difference is that it was not mandatory for the business and secretarial

TABLE 1: Education data.

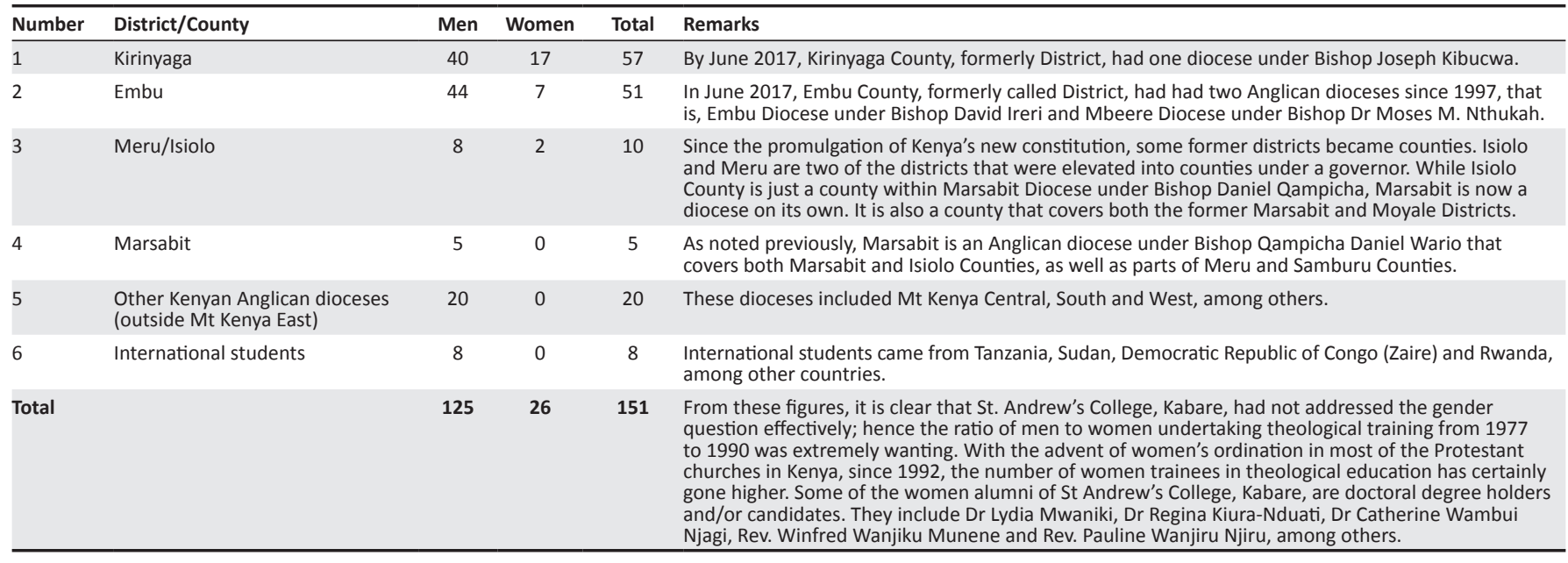


students to lead during the worship or be assigned preaching duties. The mandatory thing for both sets of students is that they were obliged by the college to attend Sunday worship in the various churches.

The third element that demonstrates practical education at St Andrew's College, especially with regard to theology trainees, is sermon evaluation (G. Ireri, interview, 10 June 2017). This was done on a weekly basis, especially for students who were undertaking the Homiletics (science of preaching) course. During that time, the preaching programme was set in such a manner that the Homiletics class would be assigned the preaching role in a particular term or semester. Likewise, the timetable would be set in a manner that the Homiletic lesson came immediately after the morning service that took place on every Wednesday morning. Considering that the Wednesday morning service was done in the spacious chapel, all students and staff attended. Nevertheless, evaluation was done in the specific class that was undertaking the relevant course. In these evaluations, various questions could be addressed: Did the preacher have a clear theme? Was his or her sermon organised in terms of title, introduction, body, conclusion and an appeal to a particular issue? Did it have enough illustrations? How did he or she employ humour and other gestures? Were facts exaggerated or stated wrongly and/or ignorantly? Did the speaker address both the immediate and the broader contexts of the biblical context correctly? With such questions, students would educate one another as the tutor and lecturer guided the debate.

A fourth element that builds on practical education is mentorship. In other words, every tutor and lecturer was a mentor to a few allocated students (G. Ireri, interview, 10 June 2017). In some cases, tutors and lecturers would call students individually in an evaluation where one had to explain more about his or her 'call' to the ministry of the church. Some other times, one could be asked personal questions by the particular mentor, regarding family background, college challenges, fears in life, marital status and plans, grading patterns and so on. In all these, tutors and lecturers were willing to guide and correct a person who had issues. After building confidence with the particular tutor and lecturer, a student felt free to tell personal matters to him or her. The challenge in this was that there was no clear structured assessment as in the case of diagnostic (ordinarily done when a teacher or tutor gets into class), formative and summative assessments, among others. At times, it would appear that it was not official and was just a conversation. However, this was both good and bad. It was good because it encouraged openness, problem-solving and understanding the student so as to help in his or her spiritual formation. However, it could be bad if the tutor and lecturer had no professional and/or resource ability to effectively address the student's challenges.

A fifth element that demonstrates practical education at St Andrew's College is the sharing of parish experiences among trainees in theology (L. Mwaniki, interview, 08 June 2017). This was normally done every Wednesday afternoon. During that time, the student community was divided into four main groups under one tutor and lecturer as the patron of the group. The student leader in each group would chair the meetings where they would discuss both the block placement and the Sunday placements. Out of these experiences, students would learn about chairing of meetings, general leadership, weaknesses and possible solutions in church ministry, mob psychology and people management and indeed would build new insights into the future of the church. In cases where the college's intervention was needed, the tutor and lecturer would liaise with the college principal and the school administration in general for a possible remedy. A case in point is when a church elder was insulting students from St. Andrew's College. This would lead the college administration to intervene and endeavour to arrest the problem. Such practical approaches taught the students on the importance of collaborative efforts and teamwork in the service of God and humanity.

\section{Critical appreciation}

While St. Andrew's College, Kabare, demonstrated holistic education, especially after 1988 when a second school (Business Studies) was added to the School of Theology, its originality as an African school was not clearly felt. Firstly, its curriculum was largely Western. Secondly, its five elements of theopractical education were a 'poor' imitation of the ancient Greek academies, where each philosopher had his own students who were schooled along certain lines and/or schools of thought. In turn, Socrates discovered that by a method of systematic probing questionings, people could not rationally justify their confident claims to knowledge (Freeman 1952). In the course of his introspection, Socrates established that one cannot depend upon those in 'authority' to have sound knowledge and insight. He noted that a person may occupy a higher leadership position yet remain deeply confused and irrational. He now sought to arrest the problem by establishing the importance of asking deep questions that that forced a person to think harder before accepting ideas as worthy of belief. In the analysis, he established the importance of seeking evidence, closely examining reasoning and assumptions, analysing basic concepts and seeking to understand the implications of whatever was said and done. In turn, his method became what is now called 'Socratic questioning' - which is a teaching methodology applicable in critical and creative thinking. Thirdly, the nature of practical education with reference to homiletics remains unclear. In other words, did it employ Christological methods? In turn, Christological trajectories, which sometimes included Socratic questioning (Mt 16:26, or 22:20-21), were spoken in authority ('You have heard this, but I tell you ...' Mt 5:22, 28, $32,34,39,44)$, were characterised by storytelling, were full of shocking and/or exceptional demands such as 'rip out our eyes and amputate our hands' (Mt 5:29-30) and/or the logs in our eyes (Mt 7:3-5). The Christological model of homiletics was also characterised by memorable sayings and quotes such as: 'Judge not, and you will not be judged; condemn not, and you will not be condemned; forgive, and you will be forgiven; give, and it will be given to you' (Lk 6:37-38a), and 
the great example of the Golden Rule of all religions of the world (Lk 6:31: 'Do unto others as you would have them do unto you').

The Christological model of homiletics was also punctuated by the use of visual illustrations such as the washing of the feet of the disciples to teach servant leadership (Jn 13:3-17); use of repetition (Mk 8:31; 9:31; 10:33-34); practising what one preaches (Lk 5:16, Mt 9:10-12); use of rhetoric (Jn 6, Mt 22:32); use of poetic forms whose artistic methods drew statements such as: ' $[d]$ o not give dogs what is holy; and do not throw your pearls before swine' (Mt 7:6); use of previous experiences such as Old Testament influences; and the use of parabolic forms, such as: 'because seeing they do not see, and hearing they do not hear, nor do they understand' (Mt 13:13; cf. Mk 4:11, 12; Lk 8:9, 10). Additionally, the Christological model of homiletics included the use of logical devices. An example of an a fortiori type of argument may be seen in the Sermon on the Mount (Mt 5-7). Here, he proceeded from the lesser example of the heavenly Father's care for the birds to the greater example of the care for humanity: 'Are you not of more value than they?' (Mt 6:26). Another methodology is reductio ad absurdum, a classic example of which is the controversy with the Pharisees over Beelzebub. Their charge that Jesus was casting out devils with the help of the prince of the devils would imply that he was making the devil war against himself, which is unthinkable. The type of argument known as ad hominem (on the basis of an opponents' premises) was often used when Jesus appealed to the teaching of the law. A typical example is when he cited the law, saying, 'you are gods' (Jn 10:34) in support of his own claim to be the Son of God. In other cases, he left his hearers to apply his illustrations on the strength of an analogy between the physical and spiritual worlds. Thus, to demonstrate the Father's willingness to give, he appeals to what might be expected from earthly fathers (Mt 7:9). Such practical gestures did not emerge explicitly as we surveyed St Andrew's College, Kabare. Nevertheless, a reconstruction of theopractical education in tropical Africa is critically important, particularly as we surge on with the reconstructive phase of theopastoral education.

\section{Conclusion}

The article began by locating the influence of Greek heritage in theopastoral education in tropical Africa. In other words, theopractical education as offered in St Andrew's College, Kabare, as in the rest of tropical Africa, is not free from Socratic questioning or Greek philosophy in general. The article also attempted to explore the nature of distorted and/ or theology that informed theopractical education in tropical Africa and the Mount Kenya region in particular, hence the need for theopastoral reconstruction. It went on to survey the goal of the establishment of St Andrew's College, Kabare, in order to ascertain the progress made so far. Has St. Andrew's provided quality theological education that is relevant for postcolonial theopastoral reconstruction? In the article, both Mugambi and Gitari seem to favour the view that trainees in Theology must have the right qualifications that can also take them to other institutions of higher learning if they so wish. The reality, however, is that the church remains in a dilemma, as it seeks to balance its physical and spiritual needs. The theological divergences that threatened to divide the church in the 1970s and 1980s because of the influence of the EARM were also explored in this article. It is interesting that St. Andrew's emerged at this critical moment in order to cover the gaping theological holes and eventually empowered both the lay and the ordained. Though initially set for the Mount Kenya East zone of the larger Mount Kenya region alone, it went beyond there and became a theological college for Kenya and beyond East Africa. In my view, the establishment of St. Andrew's College, Kabare, has huge lessons for theopastoral reconstruction for the rest of tropical Africa, as the challenges can be overcome. Nevertheless, the article has successfully demonstrated the need for theopastoral education in tropical Africa, by showcasing the case of St. Andrew's College, Kabare, in Central Kenya. It also addressed the concern in the problem statement by taking us on a journey that saw the establishment of St. Andrew's Kabare as a college of theopastoral education.

\section{Acknowledgements Competing interests}

The author declares that he has no financial or personal relationships which may have inappropriately influenced him in writing this article.

\section{References}

Barclay, W., 1977, Educational ideals in the ancient world, Baker Book House, MI. Brown, C., 1968, Philosophy and the Christian Faith, Tyndale, London. Butts, F., 1947, A cultural history of Western education, McGraw-Hill, New York. Cole, K., 1970, The cross over Mount Kenya: A short history of the Anglican Church in the diocese of Mount Kenya (1900-1970), Ridley College, Melbourne.

Freeman, K., 1952, God, man, and state, Greek concepts, Baker, London. Freeman, K.J., 1907, Schools of Hellas, Baker Book House, London.

Gathogo, J., 2013, 'Historical developments of Theological education in Eastern Africa', in Handbook of Theological Education in Africa, pp. 28-46, WCC Publication, Geneva.

Gitari, D., 1990, 'Bishop's charge', The Diocese of Mt. Kenya East, 8th Ordinary Session of Synod, Kabare, 02-04 May.

Gitari, D., 2014, Troubled But not yet destroyed: The autobiography of archbishop David Gitari. Isaac Publishing, McLean, VA.

Glover, T.R., 1931, The world of the New Testament, Cambridge.

Mugambi, J., 1995, From liberation to reconstruction: African Christian Theology after the cold war, EAEP, Nairobi.

Nieto, S., 2003, What keeps teachers going?, Teachers College Press, New York.

Synod, 1990, The 8th and last ordinary session of the Synod of the combined diocese, Diocese of Mt Kenya East, St. Andrew's Kabare, 2-4, 1990. 